\title{
Late Holocene Phytolith and Carbon-Isotope Record from a Latosol at Salitre, South-Central Brazil
}

\author{
Anne Alexandre and Jean-Dominique Meunier \\ CEREGE, Université d'Aix-Marseille III, Europôle Mediterranéen de l'Arbois, B.P. 80, 13545 Aix en Provence Cedex 4, France \\ Andre Mariotti \\ Laboratoire de Biogéochimie Isotopique, Université P. \& M. Curie, Case 120, 4 place Jussieu, 75252 Paris cedex 05, France
}

and

Francois Soubies

ORSTOM, Département TOA, UR 12, Géosciences de l'Environnement Tropical, Laboratoire de Minéralogie, UPS, 39, Allée Jules Guesde, 31000 Toulouse, France

Received February 5, 1998

The reliability of paleovegetation records inferred from soil phytolith assemblages and SOM (soil organic matter) carbon isotope analysis was examined in light of previous pollen and charcoal reconstructions. The sampled latosol is located in southcentral B razil (Salitre), at a boundary between forest and cerrado. The derived mean age of phytoliths and SOM at each level is the result of a balance between continuous translocation and selective dissolution. It increases with depth in a regular, quantifiable fashion that allows paleoenvironmental interpretation. Phytoliths and SOM tracers first record a savanna phase, associated with the last H olocene long dry period occurring between ca. 5500 and $4500 \mathrm{yr}$ B.P. Two periods of tree community development followed, between ca. 4000 and 3000 and after ca. 970 yr. B.P., leading to the present cerrado/forest association. The dry spell interrupted this trend about $970 \pm 60 \mathrm{yr}$ B.P. The second development of woody elements was contem poraneous with an increase in anthropogenic fires. Therefore, climate was more important than fires and human activities in constraining the growth of vegetation during the last nine centuries at Salitre. More generally, despite pedogenic processes, soil phytoliths and $\delta^{13} \mathrm{C}$ values of the SOM may be accurate tracers of vegetation changes. $\odot 1999$ University of Washington.

Key Words: paleoenvironment; late Holocene; soil; phytolith; carbon isotope; charcoal; Brazil.

\section{INTRODUCTION}

Soils contain charcoal, soil organic matter (SOM), phytoliths, and human artifacts that are potentially useful for reconstructing paleoenvironments. Because soils are widespread, even in dry areas where lake sediments are often lacking, bioclimatic data obtained from them are particularly desirable for reconstructing past climates. However, the reliability of paleoenvironmental interpretations of soil-particle sequences has been questioned (Cahen and Moeyersons, 1977). Particle distributions in soils are governed by four main pedogenic processes: translocation, dissolution (or mineralization), denudation, and colluviation (Johnson, 1990; Kelly et al., 1991; Colin et al., 1992; Boulet et al., 1995; Alexandre et al., 1997a). Particle translocation results from illuviation and/or fluid transportation in pores and from burrowing animals such as ants, termites, and worms, which bring to the surface materials from greater depths. Selective dissolution is related to the chemistry and surface area of the particles and to the stability of SOM/ silica particles/clays aggregates (Bartoli and Wilding, 1980). Analysis of soil particles can provide useful paleoenvironmental information only if the age of the particles at each level can be reconstructed. In this paper, we present evidence that the mean age of phytoliths and SOM in the uppermost $2.6 \mathrm{~m}$ of a latosol in central southern Brazil increases with depth in a regular, quantifiable fashion. The mean age of particles at each level results from a balance between continuous translocation and selective dissolution. We then examine the reliability of paleovegetation records inferred from soil phytolith assemblages and SOM carbon-isotope analysis by comparison with pollen and charcoal data previously published. Finally, we reconstruct the movement of a boundary between forest and cerrado and its relation with paleofires during the late Holocene period.

\section{STUDY AREA}

The study area is located near Salitre de Minas (Minas Gerais State, Brazil, $19^{\circ} \mathrm{S}, 46^{\circ} 46^{\prime} \mathrm{W}$ ) (Fig. 1). The climate is tropical, with an average annual rainfall of $1600 \mathrm{~mm}$, a 4- to 


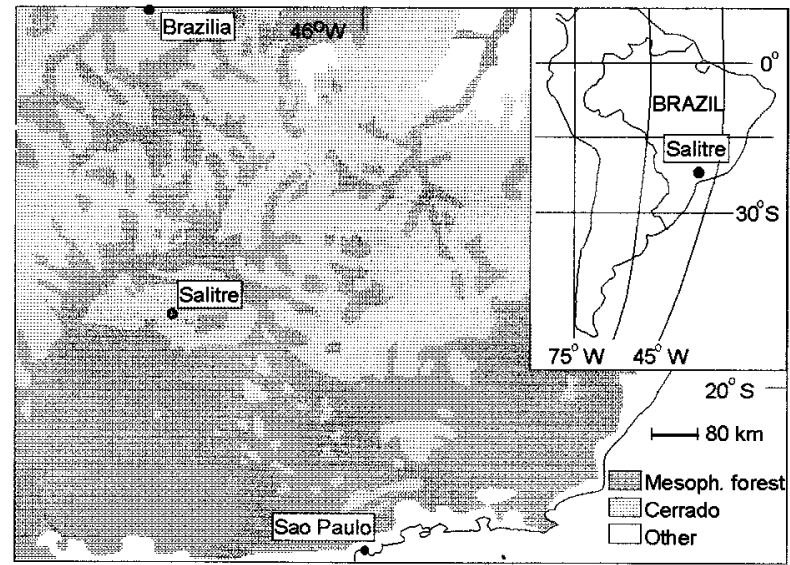

FIG. 1. Map showing location of the study area in southeastern Brazil. After Ledru (1993).

5-month dry season, and an average annual temperature of $20^{\circ} \mathrm{C}$. The area is located in a transition zone between the cerrado tree and tall grass savanna and the mesophytic semideciduous forest. Salitre is a $3.5-\mathrm{km}$-wide dolina-shaped depression lying at the center of an ultramafic-alkaline bedrock complex. The bottom of the depression lies at $980 \mathrm{~m}$ and is occupied by a peat bog from which the pollen data were obtained (Ledru, 1993; Ledru et al., 1994, 1996). The slopes are covered by latosols developed at the expense of a 50- to 100-m-thick saprolite that overlies fenitized Proterozoic quartzites and shales. The soils extend as high as $1180 \mathrm{~m}$. Denudation and colluviation do not affect these soils (Boulet $e t$ al., 1995).

The profile sampled is developed on a slope, under a forest patch surrounded by the cerrado. It is vertically zoned into six horizons separated from one another by gradational boundaries (Fig. 2a). Evidence of high biological activity includes abundant roots, filled holes (tens of centimeters in diameter) caused by roots, or animal fecal pellets. The main minerals shown by $\mathrm{X}$-ray analysis are kaolinite, gibbsite, goethite, hematite, and quartz. Pieces of charcoal (millimeters to centimeters in diameter) are scattered throughout the profile (Fig. 2b). They yield mean ${ }^{14} \mathrm{C}$ ages that increase with depth (Fig. 2 and Table 1). Their abundance-with-depth indicates that a number of fires occurred in the area between ca. 6000 and 3000 yr B.P. (Vernet et al., 1994), in conjunction with a dry phase recorded by pollen (Ledru, 1993; Ledru et al., 1994, 1996). Fifteen samples covering 5 to $20 \mathrm{~cm}$ of soil thickness were collected from 0 to $2.3 \mathrm{~m}$ depth.

\section{PHYTOLITH AND SOM CARBON-ISOTOPE ANALYSIS}

\section{Phytoliths}

Background. The basic grass phytolith classification defined by Twiss $(1969,1992)$ has shown that three grass subfamilies are discriminated by the shape of the main short cell phytoliths they produce: (1) cross and dumbbell morphotypes are produced in abundance by the Panicoideae, which consist mostly of C4 grass adapted to warm and wet environments; (2) saddle morphotype is produced in large amounts by the Chloridoideae, which consist of $\mathrm{C} 4$ grass adapted to warm and dry environments; (3) rectangular and circular morphotypes are produced in large amounts by the C3 Festucoideae. All grasses produce elongate, point-shaped, and fan-shaped morphotypes. This classification has been criticized because of multiplicity and redundancy of many grasses (Brown, 1986; Mulholland, 1989), which prevent the determination of plants on a species or genus level. However, many studies have also demonstrated that assemblage analysis is a very accurate way to characterize grass (Poaceae) communities of vegetation, which is not possible by pollen analysis (e.g., Kurmann, 1985; Piperno, 1988; Twiss, 1992; Fredlund and Tieszen, 1994; Piperno and Becker, 1996; Alexandre et al., 1997a; Fredlund and Tieszen, 1997a,b). Moreover, Alexandre et al., (1997b) demonstrated by modern and fossil phytolith assemblage analysis of sediments that the tree cover density of a given vegetation can be estimated with accuracy through the proportion of the circular rugose phytolith produced by dicotyledons. This morphotype appears relatively resistant to dissolution in latosols (Alexandre et al., 1997a). Finally, Palmae are well indicated by the circular crenate morphotype (Piperno, 1988).

Thus, phytolith analysis appears to be especially accurate for tracing forest and grassland dynamics. However, their reliability as paleoenvironmental indicators in soils has been poorly studied (Kelly et al., 1991; Piperno and Becker, 1996) because processes controlling phytolith distributions within soil profiles are barely understood.

Extraction and quantification. Following extraction of organic matter and iron oxides by wet chemical methods, phytoliths and charcoal were separated using heavy liquid from the 2- to 50- $\mu \mathrm{m}$ fraction (Kelly, 1990; Alexandre et al., 1997a) and weighed. Charcoal particles were counted under the optical microscope and subtracted from the final weight.

Taxonomy and counting. Two hundred phytoliths were counted under the optical microscope $(600 \times)$. Six morphotypes, with taxonomic significance previously described, were distinguished (Fig. 3a): (1) circular rugose, (2) circular crenate, (3) elongate, point-shaped, and fan-shaped, (4) cross and dumbel, (5) saddle, and (6) rectangular and circular. The proportion of the woody flora in the reconstructed formations is inferred from the ratio $d: p$ where $d=$ dicotyledon phytoliths and $p=$ Poaceae phytoliths (Alexandre et al., 1997b).

The modern assemblage extracted from the soil humic horizon is used as reference for the fossil assemblage interpretation. Its correlation with the surrounding vegetation is discussed on the basis of a wide investigation of cerrado grass phytoliths (Sendulsky and Labouriau, 1966; De Campos and Labouriau, 1969; Da Silva and Labouriau, 1970; Söndahl and 


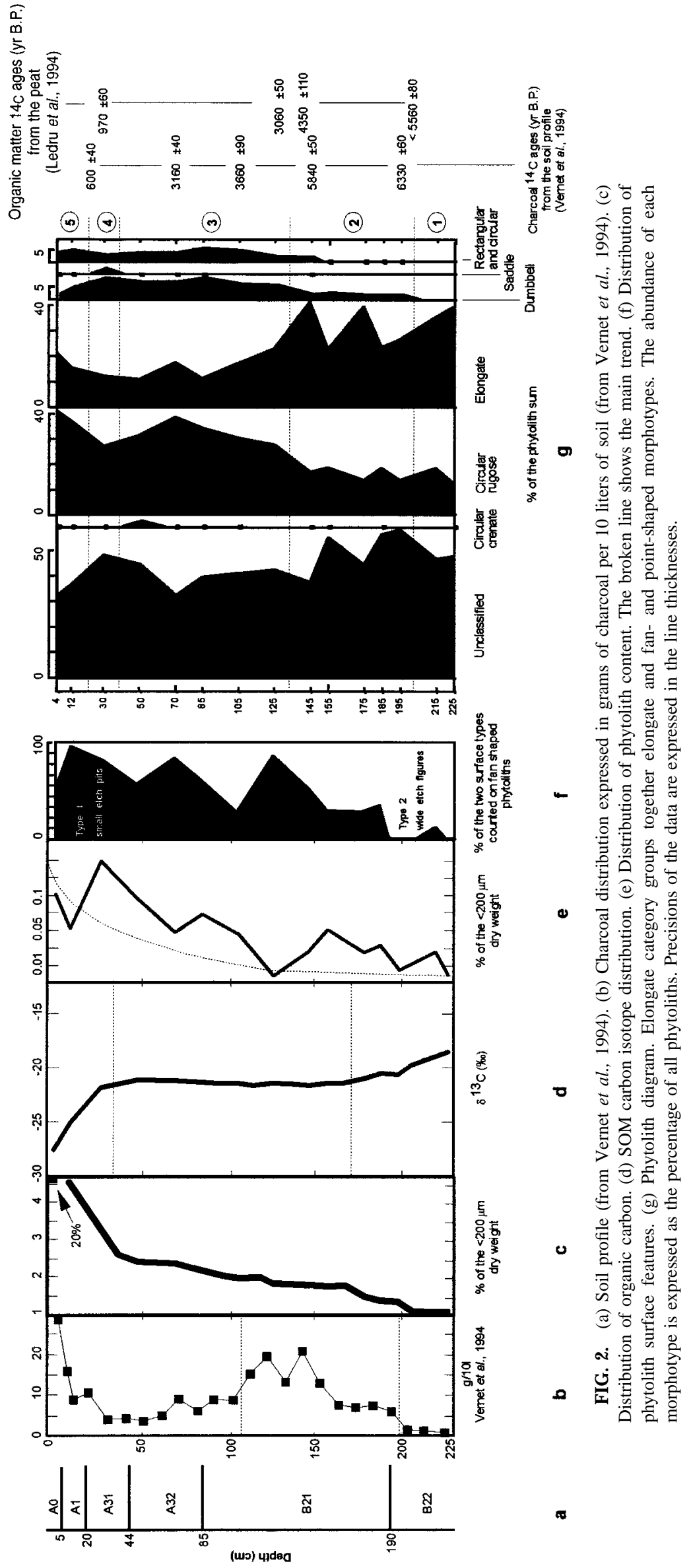


TABLE 1

Radiocarbon Dates of C harcoal from the Soil Profile and of Organic Matter (OM) from the Peat (Cores LC 91/1 and LC3)

\begin{tabular}{|c|c|c|c|c|}
\hline Lab number & Material & Depth $(\mathrm{cm})$ & ${ }^{14} \mathrm{C}$ age (yr B.P.) & Reference \\
\hline OBDY 1254 & Soil, charcoal & $20-30$ & $600 \pm 40$ & Vernet et al., 1994 \\
\hline OBDY 1255 & Soil, charcoal & $70-80$ & $3160 \pm 40$ & Vernet et al., 1994 \\
\hline OBDY 1251 & Soil, charcoal & 100 & $3660 \pm 90$ & Vernet et al., 1994 \\
\hline OBDY 1252 & Soil, charcoal & $140-150$ & $5840 \pm 50$ & Vernet et al., 1994 \\
\hline OBDY 1250 & Soil, charcoal & $180-190$ & $6330 \pm 30$ & Vernet et al., 1994 \\
\hline OBDY 970 & Peat (LC91/1), OM & $14-20$ & $970 \pm 60$ & Ledru et al., 1994 \\
\hline OBDY 551 & Peat (LC3), OM & $17-20$ & $3060 \pm 210$ & Ledru et al., 1994 \\
\hline OBDY 556 & Peat (LC3), OM & $30-32$ & $4350 \pm 525$ & Ledru et al., 1994 \\
\hline OBDY 555 & Peat (LC3), OM & $42-44$ & $5560 \pm 365$ & Ledru et al., 1994 \\
\hline
\end{tabular}

Labouriau, 1970). This investigation of cerrado grass contradicts the basic pattern of the Twiss classification on one point: C4 Panicoideae (e.g., Trachypogon, Eriochloa), which dominate the cerrado, and C4 Chloridoideae (e.g., Chloris, Eragrostis) yielded, in significant proportions, the rectangular and circular morphotypes. As no C3 Festucoideae are now widespread in the cerrado, rectangular and circular morphotypes cannot be correlated either with C3 Festucoideae or with another grass subfamily in this area.

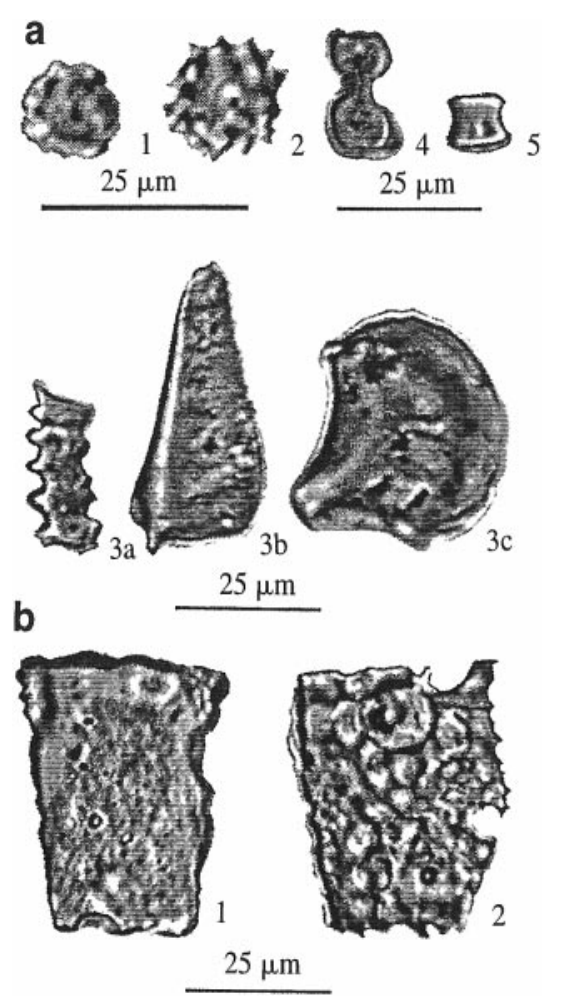

FIG. 3. (a) Microphotographs of the five morphotypes with taxonomic significance distinguished in this study: (1) circular rugose, (2) circular crenate, (3a) elongate, (3b) point-shaped, (3c) fan-shaped, (4) dumbbell, and (5) saddle. (b) Microphotographs of the two phytolith surface types: (1) with small etch pits (a few micrometers in diameter) and (2) with wide etch figures (about 10 $\mu \mathrm{m}$ in diameter).
In this study, phytolith data are discussed together with pollen data from the same area (Ledru, 1993; Ledru et al., 1994, 1996).

\section{SOM}

Measurement of organic carbon content and SOM carbon isotope analysis. The organic carbon content of the $<2-\mathrm{mm}$ fraction was measured using a $\mathrm{C}-\mathrm{H}-\mathrm{N}$ analyzer. Precision of results is greater than $0.3 \%$. The ${ }^{13} \mathrm{C} /{ }^{12} \mathrm{C}$ ratios of SOM ground, sieved, and homogenized to $<200 \mu \mathrm{m}$ were measured on a dry combustion elemental analyzer (CHN NA 1500, Carlo Erba) coupled to a Fisons SIRA 10 isotope ratio mass spectrometer (Girardin and Mariotti, 1991). Isotope abundance was expressed in $\delta^{13} \mathrm{C}$ versus PDB: $\delta^{13} \mathrm{C} \%=\left[\left({ }^{13} \mathrm{C} /{ }^{12} \mathrm{C}\right)_{\text {sample }}-\left({ }^{13} \mathrm{C} /\right.\right.$ $\left.\left.\left.\left.{ }^{12} \mathrm{C}\right)_{\mathrm{PDB}}\right) /\left({ }^{13} \mathrm{C}-{ }^{12} \mathrm{C}\right)_{\mathrm{PDB}}\right)\right] * 1000$. Repeated $\delta^{13} \mathrm{C}$ measurements of a carefully ground and homogenized reference soil yielded a precision $(1 \sigma, 8$ aliquots) of $0.06 \%$.

Background on SOM carbon isotopes. Carbon isotope fractionation between plant matter and atmospheric $\mathrm{CO}_{2}$ associated with photosynthesis is smaller for $\mathrm{C} 4$ plants than for $\mathrm{C} 3$ plants. The average $\delta^{13} \mathrm{C}$ values of $\mathrm{C} 3$ and $\mathrm{C} 4$ plants are -26 and $-12 \%$, respectively. The main control of SOM $\delta^{13} \mathrm{C}$ is litter input. However, numerous studies demonstrated that isotope fractionation during decomposition, humification, and differential preservation of ${ }^{13} \mathrm{C}$-enriched SOM components (e.g., Goh et al., 1977; O'Brien and Stout, 1978; Nadelhoffer and Fry, 1988; Martin et al., 1990; Mariotti, 1991), as well as recent variations in the ${ }^{13} \mathrm{C}$ content of atmospheric $\mathrm{CO}_{2}$ (Friedli et al., 1986; Marino and McElroy, 1991), could cause ${ }^{13} \mathrm{C}$ enrichment of forest SOM with depth. This ${ }^{13} \mathrm{C}$ enrichment is always lower than $4 \%$, far smaller than the $14 \%$ o difference between $\mathrm{C} 3$ and $\mathrm{C} 4$ plant litter. Therefore, given the time limits imposed by the turnover rate of SOM, it is possible to determine from the $\delta^{13} \mathrm{C}$ value of SOM if a change has occurred with time in the proportions of $\mathrm{C} 3$ and $\mathrm{C} 4$ plants in the overlying vegetation (e.g., Mariotti and Peterschmitt, 1994; Boutton, 1996; Desjardins et al., 1996). 


\section{RESULTS}

\section{Phytolith Data}

Phytoliths (Fig. 2e) account for $0.1 \%$ of the $<200-\mu \mathrm{m}$ fraction (dry weight) in the humic horizon $\left(A_{0}\right)$, and tend to decrease below, interrupted by three peaks of abundance at $20-40,80-90$, and $140-190 \mathrm{~cm}$ depth. They represent $0.004 \%$ of the $<200-\mu \mathrm{m}$ fraction at the bottom of the soil section.

Elongate, point-shaped, and fan-shaped morphotypes show two types of irregular surface features (Fig. 3b): small etch pits a few micrometers in diameter (type 1) and wide etch figures about $5-10 \mu \mathrm{m}$ in diameter associated with irregular and angular edges (type 2). Proportions of the two types of surface features on the fan-shaped phytoliths are illustrated in Figure 2f. Surfaces with wide etch figures increase from 0 to $100 \%$ from the top to the bottom of the soil section.

The phytolith diagram is presented as Figure $2 \mathrm{~g}$. Five zones may be discriminated on the basis of the $d: p$ ratio and of the Poaceae phytolith spectra:

Zone 1 (230-200 cm). Ratios d:p at 230 and $200 \mathrm{~cm}$, respectively, equal to 0.3 and 0.5 . The Poaceae morphotypes are only represented by the elongate, point-shaped, and fanshaped morphotypes.

Zone 2 (200-130 cm; charcoal ${ }^{14} \mathrm{C}$ dating according to Vernet et al., 1994: $6330 \pm 60 \mathrm{yr}$ B.P. at 190-180 cm and $5840 \pm 50$ yr B.P. at 150-140 cm). Among Poaceae phytoliths, dumbbell and cross morphotypes appear, remaining under 3\%; rectangular and circular morphotypes remain under $1.5 \%$; saddle morphotype is present in weak proportion only at $150-140 \mathrm{~cm}$. Ratio $d: p$ varies between 0.3 and 0.8 .

Zone 3 (130-40 cm; charcoal ${ }^{14} \mathrm{C}$ dating according to Vernet et al. (1994): $3660 \pm 90 \mathrm{yr} \mathrm{B.P.} \mathrm{at} \mathrm{110-100} \mathrm{cm} \mathrm{and}$ $600 \pm 40 \mathrm{yr}$ B.P. at 30-20 cm). Ratio d:p stabilizes around 1 and 1.3. Grass phytoliths with precise taxonomic significance become more represented: cross and dumbbell morphotypes increase, fluctuating between 6 and 9\%; saddle morphotype remains under $1.5 \%$; rectangular and circular morphotypes increase between 3 and $6 \%$ but only from $110-100 \mathrm{~cm}$.

Zone 4 (40-20 cm; charcoal ${ }^{14} \mathrm{C}$ dating according to Vernet et al., 1994: $600 \pm 40$ yr B.P. at 30-20 cm). Ratio d:p remains equal to 1 . The main feature of this zone is the significant increase of saddle morphotype, which surpasses $1.5 \%$ for the one and only time in the entire sequence.

Zone 5 (from 20 to $0 \mathrm{~cm}$ ). Ratio d:p increases to 1.5 . Among Poaceae phytoliths, cross and dumbbell morphotypes and rectangular and circular morphotypes account each for 5\% of the total phytolith sum, whereas saddle morphotype abundance is less than $1.5 \%$.

\section{SOM Data}

Organic carbon content (Fig. 2c) represents $20 \%$ of the $<2$ $\mathrm{mm}$ soil fraction (dry weight) in the organic $A_{0}$ horizon (0-5 $\mathrm{cm})$. It decreases rapidly in the organo-mineral $\mathrm{A}_{1}$ horizon $(4-20 \mathrm{~cm}$ ) to $2.7 \%$ of the $<2 \mathrm{~mm}$ soil fraction between 20 and $40 \mathrm{~cm}$ depth. It decreases gradually downward, up to $1.02 \%$ of the $<2 \mathrm{~mm}$ soil fraction at $220-230 \mathrm{~cm}$ depth. This profile does not show evidence of any buried soil or organic paleohorizon.

The distribution of the $\delta^{13} \mathrm{C}$ values of the SOM (Fig. 2d) shows three trends: (1) from the bottom of the profile up to $170-160 \mathrm{~cm}$, it decreases from -19 to $-22 \%$; (2) from 160 up to $40 \mathrm{~cm}$, it stabilizes between -22 and $-21.5 \%$; and (3) from $40 \mathrm{~cm}$, it decreases rapidly to reach $-28 \%$ in the organic horizon, which is in equilibrium with present litter inputs.

\section{DISCUSSION}

\section{Pedogenic Processes Conducing to Phytolith and SOM Distributions}

The decrease and stabilization observed with depth in the abundance of organic carbon is common to tropical and temperate soils. It may be modeled as a bicompartmental distribution, the result of particle translocation and mineralization (Jenkinson and Rayner, 1977; Parton et al., 1987). A bicompartmental distribution assumes two pools of organic compounds. One pool is recycling rapidly and is in dynamic equilibrium. The input for that pool is litter at the top of the profile. With time, the organic matter in that pool is translocated downward and is mineralized, decreasing to trace levels at the bottom of the profile. The second pool is more stable and its translocation leads to a constant abundance distribution with depth. At the base of the soil profile, nearly all of the organic matter is in the stable pool. Paleoenvironmental significance of the SOM $\delta^{14} \mathrm{C}$ and $\delta^{13} \mathrm{C}$ mean values have commonly been discussed in terms of a similar bicompartmental model (O’Brien and Stout, 1978; Balesdent and Guillet, 1982). The general pattern of the phytolith distribution is somewhat similar to that of organic carbon. We interpret it as a bicompartmental distribution, by analogy with the bicompartmental model of distribution of the SOM. Such an interpretation has been already made to discuss a phytolith distribution in a latosol of Congo (Alexandre et al., 1997a). It is here corroborated by the following points: if phytoliths surfaces with wide etch figures are more weathered than phytolith surfaces with small etch pits because of a longer residence time in the soil, their increase with depth suggests that (1) each phytolith assemblage is a mixing of young and old particles and (2) the mean residence time of phytolith assemblages increases with depth, which permits us to discuss the soil phytolith sequence as a paleoenvironmental record. 


\section{Phytolith and SOM Carbon Isotope Records}

Because of the salitre depression shape, we will assume for this discussion that the main sources of allogenic particles found in the soil (e.g., phytoliths, charcoal, organic components) are local.

Phytolith record. The Poaceae phytolith assemblage of the humic horizon corroborates the dominance of tall C4 Panicoideae over short $\mathrm{C} 4$ Chloridoideae in the present vegetation. A $d: p$ ratio of 1.5 results from the mixing between phytoliths that originated in both the forest patch and the surrounding cerrado. Using this modern assemblage as reference, five floral associations can be reconstructed from the phytolith sequence:

Zone 1 records a vegetation with abundant grasses. Woody elements are far less developed than today. The lack of short cell phytoliths characteristic of grass subfamilies would have involved grass phytolith production, dispersal, and/or preservation different than those found under modern conditions. This prevents further interpretation and indicates the limit of soil phytolith analysis.

Zone 2 records a grassland dominated by tall $\mathrm{C} 4$ grasses, with a density of tree or shrub cover far lower than the modern one. For the Holocene, only one savana phase, associated with warm and dry conditions, has been recorded at Salitre by pollen from the peat between $5560 \pm 370$ and $4350 \pm 540 \mathrm{yr}$ B.P. (Fig. 4a; Ledru et al., 1994). It was contemporaneous with an increase in fires in the area (Vernet et al., 1994). This latest and driest episode is well documented over tropical South America (Soubiès, 1980; Bradbury et al., 1981; Absy et al., 1991; Servant et al., 1993; Ledru, 1993; Ledru et al., 1996; Abbott et al., 1997; Salgado-Labouriau et al., 1997). Based on the assumption that phytoliths in the soil profile were produced by Holocene vegetation, the bottom of phytolith zone 2 would at least be younger than $5560 \pm 370 \mathrm{yr}$ B.P.

Zone 3 shows the development of trees and/or shrubs, which remain less abundant than today. This change may be related to the generation of conditions wetter than the previous ones (literature cited above) and to a decrease in fires (Vernet et al., 1994). Pollen data (Fig. 4b) have also recorded such an increase of arboreal taxa between $4350 \pm 540$ and $3060 \pm 210$ yr B.P., followed by the development of a vegetation regarded as similar to the modern one (Ledru et al., 1994). Phytolith data show, with more accuracy, that if the grass association was close to that of the cerrado, the present density of the tree cover was not reached yet.

Zone 4 records a slight decrease of trees (also corroborated by pollen data at $970 \pm 60$ yr B.P., Fig. 4b) and a brief but significant development of short $\mathrm{C} 4$ grasses. This might be related to a brief, very dry episode, which may have been contemporaneous with a mediaeval dry spell identified in Patagonia and California (Stine, 1994). The lack of data on modern paleoenvironmental changes in South America does not warrant further discussion of the significance of this event. a

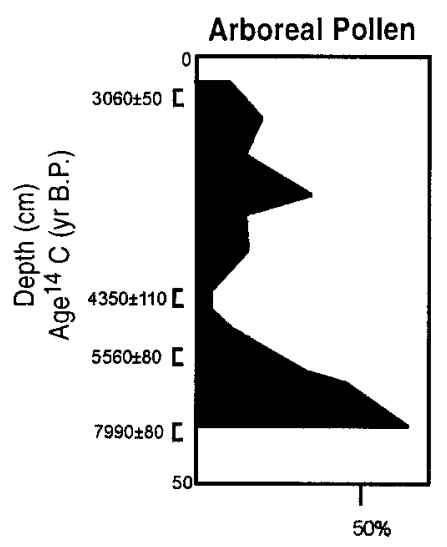

b

FIG . 4. Pollen diagrams from two cores from the Salitre peat (from Ledru et al., 1994). (a) Core LC3. (b) Core LC91/1.

Following this dry episode, zone 5 records the return of conditions more favorable for the growth of vegetation. A rapid increase in the density of shrub and tree cover and a decrease in short $\mathrm{C} 4$ grass abundance led to the present association of forest and cerrado. Finally, the phytolith record from the soil is in good agreement with pollen data from the peat and strengthens the precision of the reconstruction of the most recent vegetation changes at Salitre.

\section{SOM Carbon Isotope Record}

At the top of the profile, $\delta^{13} \mathrm{C}$ of the SOM is characteristic of a forest humic horizon (Mariotti and Peterschmitt, 1994; Desjardins et al., 1996). Decay-with-depth of SOM in equilibrium with forest inputs (C3 plants), isotope effects associated with humification, differential SOM preservation, and recent $\delta^{13} \mathrm{C}$ variations of atmospheric $\mathrm{CO}_{2}$ imply a rapid but limited ${ }^{13} \mathrm{C}$ enrichment of SOM in the topsoil, followed by a steady enrichment at lower depths, the whole enrichment being limited to 3 to $4 \%$ as generally observed (Boutton, 1996; Nadelhoffer and Fry, 1988; Mariotti and Peterschmitt, 1994). In agreement with this classic pattern, a 2-m-deep ferrallitic soil close to Salitre, assumed to be in equilibrium with forest inputs, shows a $2 \%$ enrichment, which is mostly located in the uppermost 40 $\mathrm{cm}$ (Desjardins et al., 1991). The Salitre SOM $\delta^{13} \mathrm{C}$ profile is different: the first ${ }^{13} \mathrm{C}$ shift in the uppermost $40 \mathrm{~cm}$ is greater than $7 \%$, while the second shift, in the 40 lowest $\mathrm{cm}$, accounts for $3 \%$. These features indicate two major changes in the local flora: at the bottom of the section, the SOM $\delta^{13} \mathrm{C}$ signature is the result of mixing between $\mathrm{C} 3$ and $\mathrm{C} 4$ plants, as in a tree savanna. A first increase of the density of shrubs or trees (both C3 plants) is recorded from 230 to $170 \mathrm{~cm}$ depth. A second step in the expansion of $\mathrm{C} 3$ plants is recorded above $40 \mathrm{~cm}$ depth, which led to the present association between forest and cerrado. 
Finally, both phytolith assemblages and $\delta^{13} \mathrm{C}$ values of the SOM clearly show evidence of two stages in the development of trees at Salitre after ca. 5000 yr B.P., but do so at different depths. SOM appear more rapidly translocated through lower horizons than phytoliths.

The correspondence between phytolith and pollen records permits us to place the first stage of tree expansion between $4350 \pm 500$ and $3060 \pm 210 \mathrm{yr}$ B.P. and the second after $970 \pm 60$ yr B.P. Comparison between time scales based on phytolith reconstruction and on charcoal ${ }^{14} \mathrm{C}$ dates (Fig. 2) show that phytoliths are translocated more rapidly than charcoal: for instance, the middle of the $4350 \pm 500$ to $3060 \pm 210$ yr time span recorded at $140-130 \mathrm{~cm}$ depth by phytoliths is recorded at $110-100 \mathrm{~cm}$ depth by charcoal $(3660 \pm 90 \mathrm{yr}$ B.P.). This comparison also shows that if the first development of trees corresponds to the end of a long fire period, the most recent tree expansion corresponds to an increase in fires.

\section{CONCLUSIONS}

In South America, fires could be responsible for the late Holocene variations in the boundaries between forest and savanna (Soubiès, 1980; Desjardins et al., 1996; SalgadoLabouriau et al., 1997). Our results show that at Salitre, expansion of trees between ca. 4000 and 3000 yr B.P. corresponded to a decrease in fires, in agreement with Vernet et al., (1994). This change led to the development of a vegetation association with less wood than the modern one. A dry spell, recorded by phytoliths at ca. 900 yr B.P., was not recorded by SOM $\delta^{13} \mathrm{C}$ signatures because it was mainly expressed by a change among the $\mathrm{C} 4$ grasses. It was followed by expansion of trees and an increase in human-induced fires (Vernet et al., 1994). This implies that climate was more important than fires in constraining the growth of vegetation during the last nine centuries at Salitre.

Finally, despite selective dissolution (or mineralization) in the studied soil, and mixing between young and old elements at each depth, phytoliths and $\delta^{13} \mathrm{C}$ values of the SOM are accurate tracers of vegetation changes. As impact of tropical land surface conditions on the Holocene global climate variability has been hypothesized (Gasse and Van Campo, 1994), this study shows that soil phytoliths and SOM can provide information concerning the dynamics of the major tropical vegetation assemblages, which otherwise may be unavailable for regions that lack lake sediments.

\section{ACK NOW LEDGMENTS}

This work was supported, in France, by the French programs PEGI, ECOFIT, and PROSE and by a special grant of the ORSTOM TOA Department (Action Incitative Salitre). In Brazil, support came through a FAPESP grant: Projecto Temàtico, processo 91/3518-0. The authors are especially grateful to S. Fouchet and M. Richard for SOM analysis (ORSTOM-Bondy, France) and M. Grably and C. Girardin for SOM $\delta^{13} \mathrm{C}$ analysis (Laboratoire de Biogéochimie Isotopique, UPMC, France). We also express special thanks to
S. Savin, L. Abel, L. Lumbert, F. Tessier, and M. Brooks for helpful discussions and corrections. This paper greatly benefited from reviews by D. R. Piperno and an anonymous reviewer.

\section{REFERENCES}

Abbott, M. B., Seltzer, G. O., Kelts, K. R., and Southon, J. (1997). Holocene paleohydrology of the tropical Andes from lake records. Quaternary Research 47, 70-80.

Absy, M. L., CLeef, A., Fournier, M., Martin, L., Servant, M., Sifeddine, A., Ferreira Da Silva, M., Soubies, F., Suguio, K., Turcq, B., and Van Der Hammen, T. (1991). Occurrence of four episodes of rain forest regression in southeastern Amazonia during the last 60,000 yrs. First comparison with other tropical regions. Compte Rendus de l'Academie des Sciences de Paris 312(II), 673-678.

Alexandre, A., Meunier, J.-D., Colin, F., and Koud, J.-M. (1997a). Plant impact on the biogeochemical cycle of silicon and related weathering problems. Geochimica et Cosmochimica Acta 61(3), 677-682.

Alexandre, A., Meunier, J.-D., Lézine, A.-M., Vincens, A., and Schwartz, D. (1997b). Grassland dynamics in intertropical Africa during the late Holocene: A phytolith analysis. Palaeogeography, Palaeoclimatology, Palaeoecology 136, 213-229.

Balesdent, J., and Guillet, B. (1982). Les datations par le ${ }^{14} \mathrm{C}$ des matières organique des sols. Contribution à l'étude de l'humification et du renouvellement des substances humiques. Sciences du sol 2, 93-112.

Bartoli, F., and Wilding, L. P. (1980). Dissolution of biogenic opal as a function of its physical and chemical properties. Soil Science Society of America Journal 44, 873-878.

Boulet, R., Pessenda, L. C. R., Telles, E. C. C., and Melfi, A. J. (1995). Une évaluation de la vitesse de l'accumulation superficielle de matière par la faune du sol à partie de la datation des charbons et de l'humine du sol. Exemple des latosols des versants du lac Campestre, Salitre, Minas Gerais, Brésil. Compte Rendus de l'Academie des Sciences de Paris 320(IIa), 287-294.

Boutton, T. W. (1996). Stable carbon isotope ratios of soil organic matter and their use as indicators of vegetation and climate change. In "Mass Spectrometry of Soils" (Bouttarand and Yamasaki, Eds.), pp. 47-82. Dekker, New York.

Bradbury, J. P., Leyden, B., Salgado-Labouriau, M., Lewis, W. M., Schubert, C., Jr., Binford, M. W., Frey, D. G., Whitehead, D. R., and Weibezahn, F. H. (1981). Late Quarternary environmental history of Lake Valencia, Venezuela. Science 214(4527), 1299-1305.

Brown, D. (1986). Prospects and limits of a phytolith key for grasses in the Central United State. Journal of Archaeological Science 11, 221-243.

Cahen, D., and Moeyersons, J. (1977). Subsurface movements of stone artefacts and their implications for the prehistory of Central Africa. Nature 266, 812-815

Colin, F., Brimhall, G. H., Nahon, D., Lewis, C. J., Baronnet, A., and Danty, K. (1992). Equatorial rainforest lateritic mantles: A geomembrane filter. Geology 20, 523-526.

Da Silva, S. T., and Labouriau, L. G. (1970). Corpos silicosos de Gramineas dos Cerrados. III. Pesquisa Agropecuaria Brasileira 5, 167-182.

De Campos, A. C., and Labouriau, L. G. (1969). Corpos silicosos de Gramineas dos Cerrados. II. Pesquisa Agropecuaria Brasileira. 4, 143-151.

Desjardins, T., Carneiro-Filho, A., Mariotti, A., Chauvel, A., and Girardin, C. (1996). Changes of the forest-savanna boundary in Brazilian Amazonia during the Holocene revealed by stable isotope ratios of soil organic carbon. Oecologia 108, 749-756.

Desjardins, T., Volkoff, B., Andreux, F., and Cerri, C. C. (1991). Distribution du carbone total et de l'isotope ${ }^{13} \mathrm{C}$ dans des sols ferrallitiques du Bresil. Science du Sol 29, 175-187. 
Fredlund, G. G., and Tieszen, L. L. (1994). Modern phytolith assemblages from the North American Great Plains. Journal of Biogeography 21, 321-335.

Fredlund, G. G., and Tieszen, L. L. (1997a). Phytolith and carbon isotope evidence for late quaternary vegetation and climate change in the southern Black Hills, South Dakota. Quaternary Research 47, 206-217.

Fredlund, G. G., and Tieszen, L. L. (1997b). Calibrating grass phytolith assemblages in climatic terms: application to late Pleistocene assemblages from Kansas and Nebraska. Palaeogeography, Palaeoclimatology, Palaeoecology 136, 199-211.

Friedli, H., Lotscher, H., Oeschge, H., Siegenthaler, U., and Stauffer, B. (1986). Ice core record of the ${ }^{13} \mathrm{C} /{ }^{12} \mathrm{C}$ ratios of atmospheric $\mathrm{CO}_{2}$ in the past two centuries. Nature 324, 237-238.

Gasse, F., and Van Campo, E. (1994). Abrupt post-glacial climate events in West Asia and North Africa monsoon domains, Earth and Planetary Science Letters 126, 435-456.

Girardin, C., and Mariotti, A. (1991). Analyse isotopique $\mathrm{du}{ }^{13} \mathrm{C}$ en abondance naturelle dans le carbone organique: Un systeme automatique avec robot preparateur. Cahier Orstom, Serie Pédologie XXVI 4, 371-380.

Goh, M., Stout, J. D., and Rafter, T. A. (1977). Radiocarbon enrichment of soil organic matter fractions in New Zealand soils. Soil Science 123, 385-391.

Jenkinson, D. S., and Rayner, J. H. (1977). The turnover of soil organic matter in some of the Rothamsdet classical Experiments. Soil Science 123(5), 298-305.

Johnson, D. L. (1990). Biomantle evolution and the redistribution of earth materials and artifacts. Soil Science 149(2), 84-102.

Kelly, E. F. (1990). "Method for Extracting Opal Phytoliths from Soil and Plant Material." Unpublished internal document, Department of Agronomy, Colorado State Univ., Fort Collins.

Kelly, E. F., Amundson, R. G., Marino, B. D., and Deniro, M. J. (1991). Stable isotope ratios of carbon in phytoliths as a quantitative method of monitoring vegetation and climate change. Quaternary Research 35, 222-233.

Kurmann, M. H. (1985). An opal phytolith and palynomorph study of extant and fossil soils in Kansas (U.S.A.). Palaeogeography, Palaeoclimatology, Palaeoecology 49, 217-235.

Ledru, M.-P. (1993). Late quaternary environmental and climatic changes in Central Brazil. Quaternary Research 39, 90-98.

Ledru, M.-P., Behling, H., Fournier, M., Martin, L., and Servant, M. (1994). Localisation de la forêt d'Araucaria du Brésil au cours de l'Holocène. Implications paléoclimatiques. Compte-Rendus de l'Academie des Sciences de Paris 317, 617-521.

Ledru, M.-P., Soares Braga, P. I., Soubies, F., Fournier, M., Martin, L., Suguio, K., and Turcq, B. (1996). The last 50,000 years in the Neotropics (Southern Brazil): Evolution of vegetation and climate. Palaeogeography, Palaeoclimatology, Palaeoecology 13, 239-257.

Marino, B. D., and McElroy, M. B. (1991). Isotopic composition of atmospheric $\mathrm{CO}_{2}$ inferred from carbon in $\mathrm{C} 4$ plant cellulose. Nature 349, 127-131.

Mariotti, A. (1991). Le carbone-13 en abondance naturelle, traceur de la dynamique de la matière organique des sols et de l'évolution des paléoenvironnements continentaux. Cahiers Orstom, Serie Pedologie XXVI, 299-313.

Mariotti, A., and Peterschmitt, E. (1994). Forest savanna ecotone dynamics in
India as revealed by carbon isotope ratios of soil organic matter. Oecologia 97, 475-480.

Martin, A., Mariotti, A., Balesdent, J., Lavelle, P., and Vuattoux, R. (1990). Estimate of organic matter turnover rate in a savanna soil by ${ }^{13} \mathrm{C}$ natural abundance. Soil Biology Biochemistry 22(4), 517-523.

Mulholland, S. C. (1989). Phytolith shape frequencies in North Dakota grasses: A comparison to general patterns. Journal of Archaeological Science 16, 489-511.

Nadelhoffer, K. J., and Fry, B. (1988). Controls on natural nitrogen-15 and carbon-13 abundances in forest soil organic matter. Soil Science Society of America Journal 52, 1633-1640.

O'Brien, B. J., and Stout, J. D. (1978). Movment and turnover of soil organic matter as indicated by carbon isotope measurements. Soil Biology Biochemistry 10, 309-317.

Parton, W. J., Schimel, D. S., Cole, C. V., and Ojima, D. S. (1987). Analysis of factors controlling soil organic matter levels in Great Plains grasslands. Soil Science Society of America Journal 51, 1173-1179.

Piperno, D. R. (1988). "Phytolith Analysis: An Archaeological and Geological Perpective.” Academic Press, San Diego.

Piperno, D. R., and Becker, P. (1996). Vegetational history of a site in the central Amazon basin derived from phytolith and charcoal records from natural soils. Quaternary Research 45, 202-209.

Salgado-Labouriau, M. L., Casseti, V., Ferraz-Vicentini, K. R., Martin, L., Soubies, F., Suguio, K., and Turcq, B. (1997). Late Quaternary vegetational and climatic changes in cerrado and palm swamp from Central Brazil. Paleogeography, Palaeoclimatology, Palaeoecology 128, 215-226.

Sendulsky, T., and Labouriau, L. G. (1966). Corpos silicosos de Gramineas dos Cerrados. I. Anais de Academia Brasileira de Ciencas 38, 159-196.

Servant, M., Maley, J., Turcq, B., Absy, M.-L., Brenac, P., Fournier, M., and Ledru, M.-P. (1993). Tropical forest changes during the late Quaternary in African and South American lowlands. Global and Planetary Change 7, $25-40$.

Söndahl, M. R.-I., and Labouriau, L. G. (1970). Corpos silicosos de Gramineas dos Cerrados. IV. Pesquisa Agropecuaria Brasileira 5, 183-207.

Soubiès, F. (1980). Existence d'une phase sèche en Amazonie brésilienne datee par la presence de charbons dans les sols (6000-3000 ans BP). Caiers ORSTOM, Serie Geoologie 11(1), 133-148.

Stine, S. (1994). Extreme and persistent drought in California and Patagonia during medieval time. Nature 369, 546-549.

Twiss, P. C. (1969). Morphological classification of grass phytoliths. Soil Science Society of America Proceeding 33, 109-115.

Twiss, C. (1992). Predicted world distribution of C3 and C4 grass phytoliths. In "Phytolith Systematics" (G. Rapp and S. C. Mulholland, Eds.). Plenum, New York.

Vernet, J.-L., Wengler, L., Solari, M.-E., Ceccantini, G., Fournier, M., Ledru, M.-P., and Soubies, F. (1994). Feux, climats et végétations au Brésil central durant l'Holocène: Les données d'un profil de sol à charbons de bois (Salitre, Minas Gerais). Compte-Rendus de l'Academie des Sciences de Paris 319(II), 1391-1397. 